\title{
RATE CONTROL UNDER THE AMENDED INTERSTATE COMMERCE ACT
}

\author{
By Harrison Standish Smalley, Ph.D., \\ University of Michigan, Ann Arbor, Mich.
}

Under the Interstate Commerce Act, as originally passed in 1887, the Commission assumed that it possessed the power to prescribe rates for railroad companies. In 1896 and 1897 , however: the Supreme Court rendered decisions ${ }^{1}$ denying this power and announcing that while the commission might declare existing rates unreasonable, it was not empowered by the act to substitute other rates to be observed in future. Thus shorn of its authority, the commission appealed to Congress for a restoration of it, and, as the years passed by, repeatedly renewed its petition. For several years, however, Congress steadfastly turned a deaf ear to its prayers, until public opinion, awakened largely by the President, came to the aid of the commission. By I904 there had been manifested an impressive public sentiment in favor of railroad reform, and under this stress the Esch-Townsend bill achieved a remarkable success in the house. But the senate compassed its downfall. Nevertheless, during the succeeding months, popular sentiment continued to grow, and in consequence, when the members of Congress next assembled, in December of 1905, it was generally agreed among them that railroad legislation of some sort would have to be enacted. Moreover, it was almost as generally acknowledged that one feature of the legislation would have to be a grant of the rate-making power to the Interstate Commerce Commission.

But the recognition that this step was practically inevitable did not altogether do away with consideration of its general policy. Especially, at first, was much oratory devoted to its constitutional features. But all such discussion speedily dwindled in importance, and it was soon recognized that the significant feature of the Congressional task was the formulation of the various specific provisions of the law. Granted that the commission should have the

1162 U. S. 184 , and 167 U. S. 479.

(292) 
rate-making power, the real struggle was involved in the determination of the character and limitations of that authority. In this connection several important questions arose, and the earnest debates upon them revealed a wide difference of opinion between the extreme conservatives and the extreme radicals. Untimately, however, a compromise was reached on each point, and at the eleventh hour the bill was passed and became a law.

The more important of the questions which presented themselves to Congress pertained to the following matters: (I) The rates which should be made subject to the commission; (2) the circumstances under which the commission should be authorized to prescribe rates; (3) the character of the rates thus established; (4) the review of these rates by the courts; (5) the expedients which should be adopted to mitigate the evils resulting from judicial review; and (6) the penalties to be imposed for the violation of the commission's orders establishing rates. It is the purpose of this article to discuss the manner in which these subjects are treated in the Interstate Commerce Act as now amended.

r. The Rates Subject to the Commission.-To begin with, the rate-making power of the commission applies to all common carriers by rail, or by both rail and water, when both are under common control or management, or arrangement for a continuous carriage. It also applies to express companies, sleeping car companies, and all corporations or persons operating pipe lines, ${ }^{2}$ the insertion of these provisions being the outcome of extended discussion in Congress. The power extends to all rates not purely intrastate, whether charged for the transportation of persons or property, and it is clearly the design of the act that the charges for all services rendered in connection with such transportation shall be under the control of the commission. Many elements to be regarded as included in the term "transportation" are enumerated in the first section, and it is interesting to note that they embrace, among other things, "all services in connection with the receipt, delivery, elevation, and transfer in transit, ventilation, refrigeration or icing, storage and handling of property transported." The commission is also granted a limited authority over joint rates. When two or more connecting carriers, one of whom may be a carrier by water, have failed to establish through routes and joint rates, and no

sother than for the transportation of water and natural or artificlal gas. 
reasonable or satisfactory through routes exist, the commission may, on complaint, establish such through routes and prescribe the rates applicable thereto. Finally, the power of the commission covers the allowances made by carriers to shippers who directly or indirectly render any service in connection with the transportation of their goods, this provision being designed to remedy a familiar form of discrimination. Thus it will be seen that a very comprehensive authority is accorded the commission, its one weakness, probably, being a lack of power over transportation exclusively by water.

2. When Rates May be Made.-A second matter of importance has reference to the circumstances under which the commission may establish rates. In determining this question three alternatives were open to Congress. The commission might be required to wait until complaints of unreasonable rates were brought to it before it could move in the matter of rate-making. Such a provision would give it something of the character of a court, which cannot seek cases to decide, but must wait until the parties voluntarily institute proceedings. Or, secondly, the commission might be empowered to take the initiative in the matter, establishing rates on its own motion, though, of course, after proper investigation and hearing. Or, thirdly, it might be given, practically if not nominally, the status of chief traffic manager for the various railroad companies. While, in such a case, the entire work of rate-making would not be placed in its hands, the final authority and responsibility would be lodged there. Of these three forms of rate control, Congress elected to adopt the mildest. The commission is empowered to act only upon complaint; it cannot take the initiative. Such a limited power, of course, gives rise to a serious difficulty. The establishment of certain rates, following a complaint, may render highly desirable the readjustment of other related rates; yet the commission is writhout authority to touch them, until and unless a complaint is filed. There is, however, another provision of the act which opens an avenue of escape from this difficulty. It is provided that "no complaint shall at any time be dismissed because of the absence of direct damage to the complainant." Thus it is possible for the commission, if it desires to investigate rates, to set up dummies to bring the formal complaints demanded by the act. This is, of course, a nuisance, and may involve some small sacrifice of official dignity, 
but aside from these embarrassments the commission is as much at liberty to investigate rates as if the right of initiative had been granted to it.

3. The Character of the Rates.-Two things may be said as to the character of the rates to be established by the commission. First, they are to be merely the maximum. No power is given to fix an absolute rate, or to prescribe a minimum charge. Of course a maximum rate is to a limited extent a minimum rate as well, inasmuch as many reductions from it can be assailed as unjustly discriminatory, and so can be prevented; but obviously this is not true of all reductions. Hence it is thought by many that the failure of the act to provide for minimum rates is unfortunate, especially because it may impair the enforcement of differentials by the commission. It must be confessed, however, that the establishment of a minimum rate appears to be beyond the powers of Congress. Though this question has never been judicially determined, and so must be regarded as somewhat uncertain, little doubt remains after a consideration of the following facts. The Supreme Court has come just short of deciding that the power of the states is limited to the fixing of maximum rates. The point has never been directly at issue before the court, and so an absolutely final dictum has not been given; but repeatedly, from the earliest cases to the present time, the court, in asserting the states' power over rates, has defined it as an authority to fix a maximum. The court has never positively stated that a minimum is beyond the states' power, because it has never had occasion to decide the question, but its constant employment of "maximum" or other words of like import in defining that power is all but conclusive on the point. This being true, the thought naturally occurs that if the people of the several states do not possess the right to fix a minimum rate, they could hardly have conferred that right upon Congress. However, in spite of this consideration, it is regarded as unfortunate that Congress did not in the act provide for a minimum rate. The point would then come up for judicial interpretation and would be settled. Even were the provision declared to be beyond the competence of Congress, its rejection would not impair the validity of the balance of the act; and were it sustained it would doubtless strengthen the hands of the commission.

A second provision as to the character of the commission's 
rates is that they shall be just and reasonable, but the discussion of this requirement will be undertaken under our next head.

4. Judicial Reviezw.-Of all the questions which presented themselves to Congress, none matched in importance that which pertained to the review by the courts of rates prescribed by the commission. It was generally recognized that upon the answer to this question, more than upon anything else, depended the effectiveness of the provision for rate regulation. For the purpose of judicial review is to determine whether, in prescribing rates, the commission has exceeded its powers, and to restrain its action if such has been the case. The inquiry of the courts may take different directions. It may be designed to discover whether the charges which have been regulated are among those subject to the commission, or whether that board has complied with the requirements of the act as to its procedure in the investigation and establishment of rates; but by all means the most important specific aim of judicial review is to determine whether the rates prescribed by the commission are unduly low, and if they are, to restrain their enforcement. Were the courts to possess no right of review there would be no limit to the commission's power of rate reduction, except its own discretion. It might reduce rates to zero. Judicial review, then, is a restraint upon the commission's power of rate control, and the broader that review, the more circumscribed is the authority of the commission. This is why the question was acknowledged to be the very heart of the whole problem. Though the ratemaking power might be granted in terms, it might be practically nullified by conferring upon the courts a very broad right of review. In any case, the strength of the commission would largely depend upon the character of the provision for judicial review.

Doubtless the simplest plan would have been to say nothing at all upon the subject in the act, and this suggestion was not without its advocates. But it was vigorously opposed by the representatives of the railroad interests, together with other conservatives, who expressed the fear that if the act were silent on the matter it might be declared unconstitutional, as denying the right of review to the courts. Most persons, however, were not affected by this apprehension. It was evident to them that the courts needed no authorization from Congress to review the commission's rates; that the constitution itself confers that right. The constitution not only 
bestows upon Congress the power to regulate commerce, but it also provides, as a limitation upon the federal government, that no person shall be deprived of property without due process of law and without just compensation: Beyond a doubt, then, the courts would not permit rates made by Congressional authority, under the commerce clause, to be enforced, if they contravened that other and more recently adopted provision regarding deprivation of property. Congress cannot, under the guise of legislating in pursuance of one clause, violate another, especially a more recently adopted provision. As the guardians of the constitution, the courts would be aburidantly competent to pass upon the constitutionality of rates made by the commission, and so, without any provision in the act, the commission's rates would be subject to judicial review.

But though this seemed clear, the reform element in Congress was not in a position to insist upon the silence of the act, for such insistence might cast suspicion upon their good faith. If they believed that judicial review ought to exist, what objection could they have to saying so in the act? Therefore it was conceded that some provision on the subject should be enacted.

That being settled, the next step was to formulate the provision, and this involved the determination of the power which should be conceded to the courts, and, conversely, to the commission. Obviously here, again, two courses were open. The act might simply state that the courts should be competent to pass upon the constitutionality of the rates; or, it might give them a broader right of review. To put it otherwise, the act might simply aim to protect the railroads in the enjoyment of their constitutional rights, or it might confer on them additional rights, and charge the courts with the duty of protecting them. In the former case the commission would possess just the same power over interstate rates that state commissions have over local tariffs; in the latter, it would have a more limited authority.

The natural course would have been to adopt the former alternative, confining the courts to an adjudication of the constitutional question; but the conservative element, inspired by its late victory, felt emboldened to stand out for a broader right of review, with the purpose of weakening the commission's efficiency. The result was a struggle which lasted until late in June, when it was terminated by a compromise. The curious feature of this compromise 
is that no one can be absolutely sure of its meaning. The wording of the act as it now stands is to some extent indefinite and ambiguous, and not until a case has been passed upon by the Supreme Court will its meaning be surely known. At this time all that can be done is to call attention to the various clauses of the act bearing upon the question, and to indicate some of the considerations to which weight will doubtless be attached by the court.

The clause which confers the power of review is as follows:

The venue of suits brought in any of the circuit courts of the United States against the commission to enjoin, set aside, annul, or suspend any order or requirement of the commission shall be in the district where the carrier against whom such order or requirement may have been made has its principal operating office, and may be brought at any time after such order is promulgated. And if the order or requirement has been made against two or more carriers then in the district where any one of said carriers has its principal operating office, and if the carrier has its principal operating office in the District of Columbia then the venue shall be in the district where said carrier has its principal office; and jurisdiction to hear and determine such suits is hereby vested in such courts.

It will be seen that this clause is wholly indefinite. It vests in the circuit courts the power to hear and determine suits to set aside, annul, or suspend any order of the commission, but it says nothing as to the ground on which the courts can set aside the commission's rates. May they annul them on the ground of unconstitutionality alone, or on some other ground? To this question no direct answer is given, and therefore the various provisions of the act must be scrutinized to see if they reveal the Congressional intent. Power to judge of the constitutionality of the rates is surely in the hands of the courts, but if they possess any other or broader power, it must be because the act confers it upon them.

Looking into this question, we find several clauses in the amended act which seem to bear upon it. One, found in the first section, simply repeats with a slight modification a provision in the original act. It is the general, sweeping declaration that all rates and charges "shall be just and reasonable; and every unjust and unreasonable charge . . . is prohibited and declared to be unlawful."

Another clause of importance in this connection is found in section I5, where the rate-making power is conferred on the commission. "The commission is authorized and empowered, and it 
shall be its duty . . . to determine and prescribe what will be the just and reasonable rate or rates, charge or charges to be thereafter observed." And later in the same section the commission is authorized to "determine what is a reasonable charge" to be paid by a carrier to a shipper who renders some service in connection with the transportation of his goods.

It is evident from these citations that Congress intends all rates to be reasonable. Even the commission is placed under the duty of prescribing "what will be the just and reasonable rate or rates." This being true, the question of the interpretation which the courts will give to this requirement becomes a matter of great moment. How will they undertake to determine whether rates are reasonable or not? By what standards will they judge them?

The word "reasonable" is the despair of the layman, and surely can be scarcely less distressing to the members of the legal profession. The multitude of considerations-ethical, economic, social and political, as well as strictly legal-which must be taken into account in discovering what is reasonable in any connection. together with scarcity of guiding principles general enough to be true, yet concrete enough to be useful, conspire to make the task one of greatest difficulty. The reasonableness of railroad rates furnishes no exception to this rule. Yet amid all the confusion of infinite detail one fact is clear. There are but two avenues along which the courts have ever attempted to proceed in judging of the reasonableness of rates. There are, in other words, but two judicial tests of reasonableness. One may be termed the test of "constitutionality," and the other the test of "remuneration." The principles and methods according to which these tests should be applied are at present involved in much uncertainty, but the tests themselves may nevertheless be clearly distinguished.

The constitutional test has been repeatedly applied in cases involving rates made by state legislatures and commissions, and so its general nature is well understood. Its aim is to discover whether the rates are of such a character as to violate the Federal Constitution, for if they are, they must be held to be unreasonable. The precise question which arises relates to the Fourteenth Amendment, which provides that no person shall be deprived of property without due process of law. The term "due process of law," as interpreted by the courts, embraces more than the mere formal proceedings 
characteristic of a tribunal of justice. In it is included the further idea of "just compensation." Due process of law is not observed in the appropriation of private property by the state unless the owner is adequately recompensed, and this, indeed, is the most significant element in "due process." In judging, then, of the constitutionality of rates, the courts must determine whether the state, without providing for compensation, has imposed rates which are so low as to deprive the railroads of property.

But how is it that rates may "deprive of property?" Clearly they cannot operate in such a manner as to appropriate any of the tangible property of a railroad company. But the courts hold that under the Fourteenth Amendment a person is entitled to protection against the seizure, without compensation, not only of his property, but of its fruits as well, which in the eyes of the law are property. Hence a railroad company, though subject to public control of its rates, is constitutionally entitled to a reasonable income from its business, and the imposition of rates which are so low as to prevent it from earning such an income amounts to a deprivation of its property.

At this point the judicial doctrine is confronted by another difficulty. What is a reasonable income from a railroad's business? It will not promote our present purpose to inquire into this question in detail. It will be sufficient to observe that the courts have decided that no definite rate of net income can be stated; that it must vary with the circumstances of each case; that in an extreme case it might even be equal to zero; and that, whatever the rate is, it must be reckoned on the actual value of the property, rather than on its original value, on the company's capitalization, or on any other base. Beyond this we shall not go, ${ }^{3}$ for it is desired simply to make clear the nature of the "constitutional test." Whether rates are reasonable depends on whether they are high enough to permit the railroad company to earn a reasonable income from its business. The rates are judged according to their effect upon the net returns of the business.

Now the "test of remuneration" must be sharply distinguished from this. It is not concerned with the company's income, but

For a full discussion of the principles and methods of the courts in applyIng this test of constitutionalsty, see the author's "Rallroad Rate Control In its Legal Aspects," Publications of the American Economic Association, May, 1906. 
rather with the separate services rendered by the company to its patrons. Its aim is to secure for the railroad a reasonable remuneration for each service rendered. Of course the difficulty arises of determining what a "reasonable" remuneration is, and into that question we cannot go, save to remark that it is to be determined, among other things, by the nature and cost of the service, and by its importance and value to the shipper, the customary rate, if there is one, being strong evidence of what is reasonable. The validity of the rates, then, under this test, is a matter of their relation to the services rendered by the company, which is entitled to a just compensation for each service. Now, of course, it can be imagined that according to this standard rates might be recognized as reasonable, though so low as not to yield a reasonable income, and that consequently this might not be so favorable to the railroad as the constitutional test. But while such a case is conceivable, it is highly improbable. It is much more likely that the remuneration test would prove more favorable; that under it rates held to be but barely reasonable would yield a large income. In the words of $\mathrm{Mr}$. Justice Brewer," if a carrier "has a thousand transactions a day and his charges in each are but a reasonable compensation for the benefit received by the party dealing with him, such charges do not become unreasonable because by reason of the multitude [of his transactions] the aggregate of his profits is large."

At this point an inquiry is natural. How do the courts use these two tests of reasonableness? When do they apply one and when the other? As already intimated, they employ the constitutional test in cases where rates are involved which have been made by public authority. They employ the other in cases where no government interference has occurred, but where there is simply a dispute between the road and an individual shipper. By the common law a common carrier is entitled to a reasonable compensation for each service, and if sued by a shipper for overcharge, this is the point considered by the courts in determining whether there has been an excessive exaction. One test, therefore, is used in cases of government-made rates; the other in private disputes as to the fairness of charges, in the absence of governmental regulation.

Still another distinction in the use of these two tests was suggested by $\mathrm{Mr}$. Justice Brewer some five years ago. In his

In Cotting v. Kansas City Stock Yarda Co., 183 U. \$. 70, 95.

(3OI) 
opinion, in Cotting $v$. Kansas City Stock Yards Company, ${ }^{8}$ he called attention to the fact that there are two classes of industries subject to public control of their rates-those which are public, and those which, though private in nature, have become so "affected with a public interest" as to be fit subjects for such regulation. He then questioned whether the legislature should be allowed to go so far in controlling charges in private business as in public, and expressed the conviction that it should not; that while a public business is entitled, in spite of legislative enactments, to no more than rates high enough to yield a reasonable income, a private business should be allowed to collect a reasonable charge for each service, though the resultant earnings might be great. In short, he advocated the application of the constitutional test to public business, and of the remuneration test to private business. ${ }^{\circ}$

We are now prepared to note the consequences that would flow from the adoption by the courts of either of these tests in judging of the reasonableness of rates made by the Interstate Commerce Commission. Were the constitutional test to be applied, the commission would have just the same power over rates that any state commission may have, and no more; but were the remuneration test to be employed, its authority would be more narrowly limited. It could go no farther than the common law itself. The railroads would be entitled to rates just as high as they could law fully demand, even in the absence of Congressional regulation. In other words, the commission would be prevented from reducing their rates below the maximum amount which they were legally entitled to receive before the commission was created. The action of Congress in bestowing the rate-making power on the commission would be in large part futile, for it would not result even in the possibility of lowering the legal maximum for rates.

Yet this is exactly the situation which some of the conservatives in Congress desired to bring about, and for which they labored most arduously. It was their endeavor to secure the insertion in the bill of words which would require the courts to apply the remuneration test. For example, a provision that the rates made by the com-

183 U. S, 79.

-It must be stated that these remarks of Justlce Brewer's were obiter dicta, and therefore stand only as the expression of his personal opinion, not as settled Iaw. Nevertheless they are entitled to great wejght because of the recognized learn. Ing and abllity of their distinguished author. 
mission should be "fairly remunerative" was placed in the bill, and remained there until the final compromise. Had they not been eliminated, the ambition of the conservatives would probably have been realized. For they might reasonably have been interpreted by the courts as requiring the test of remuneration.

But it is our special purpose to consider the effect of the act as finally passed. Containing, as it does, the simple requirement that rates must be reasonable, which method of determining reasonableness will the Supreme Court adopt? Of course it is evident that the court alone can furnish a final answer to this question. It is not bound by precedent or other authority, and can use its own discretion. There are certain considerations, however, which point toward its adoption of the constitutional test, and these may be briefly noticed.

In the first place, it must be recognized that rate-making is a legislative function, in the exercise of which the commission is simply acting for Congress and doing its will. Now there is no question that Congress may regulate rates, subject only to constitutional restraints. And it would be hardly proper to assume that Congress meant to limit itself or the commission to a more narrow authority unless that intention clearly appeared. Having granted the commission the rate-making power, it should be presumed that Congress granted it the full power, subject only to such restraints as the constitution or the act itself imposes. And therefore, unless the act in definite terms more narrowly confines its activity, the commission should be allowed to go to the constitutional limit. But the act contains no such definite terms. Therefore the standard of reasonableness should be the constitutional test, and not that of remuneration.

But more definite reasons for the same belief are to be found in the decisions of the court in cases involving rates made by state authority. In reading these cases, one cannot fail to notice that the court repeatedly speaks of its task as involving a determination of the "reasonableness" of the rates. Such quotations as the following will serve to illustrate the point. "It was therefore within the competency of the Circuit Court to enter upon an inquiry as to the reasonableness and justice of rates prescribed by the railroad commission." "The legislature has power to fix rates, and the limit of

T154 ข. 8. 399 . 
judicial interference is protection against unreasonable rates." "The more difficult question is that connected with the reasonableness of the rates." But while the court has thus asserted its right and duty to guard the railroads against the enforcement by the state of "unjust" and "unreasonable" rates, it is noteworthy that it consistently employs the constitutional test. Would not the same practice naturally be followed in testing the "reasonableness" of the commission's rates?

It is also a significant fact that two clauses of the act requiring "reasonableness" are substantially the same as those present in various state commission laws which have come under the official scrutiny of the court. Thus a general clause commanding that all rates be reasonable was present in the Iowa act, ${ }^{10}$ involved in Chicago and Northwestern Ry. Co. v. Dey ${ }^{11}$ in the South Dakota act, ${ }^{12}$ involved in Chicago, Milwaukee and St. Paul Ry. Co. $v$. Tomkins, ${ }^{13}$ and in the Minnesota act, ${ }^{14}$ involved in Minneapolis and St. Louis Rd. Co. $v$. Minnesota. ${ }^{15}$ Moreover, the additional specification that the commission should prescribe reasonable rates appeared in all of the acts just mentioned, and also in the Texas act, ${ }^{10}$ involved in Reagan $v$. Farmers' Loan and Trust Co. ${ }^{17}$ Yet in all of these cases the reasonableness of the rates was determined according to the constitutional standard. In the light of this practice, is it likely that the Supreme Court will feel justified in interpreting similar clauses in the Interstate Commerce Act as justifying any other test of the commission's rates?

One or two other considerations point in the same direction. Section 16 of the act provides that "if any carrier fails or neglects to obey any order of the commission, other than for the payment of money," any party injured thereby or the commission itself may institute legal proceedings. And "if, upon such hearing as the court may determine to be necessary, it appears that the order was regu-

143 U. S.. 344.

186 U. S. 264 ; and for other examples see 169 U. S. 546 ; 176 U. S. 174 ; and 154 TJ. S. 397.

${ }^{10}$ Laws of 1888, Chap. 28.

1135 Fed. Rep. 866.

${ }^{12}$ Laws of 1897, Chap. 110.

${ }^{15} 176$ U. S. 167 .

14General Statutes for 1804, Sec. $\mathbf{3 8 0 .}$

15186 U. S. 257.

${ }^{10}$ Laws of 1891 , p. 55 .

17154 U. S. 362 . 
larly made and duly served, and that the carrier is in disobedience of the same, the court shall enforce obedience to such order by a writ of injunction or other proper process." The significance of this provision seems to be clear. When an order of the commission prescribing rates is disobeyed the commission may petition the Circuit Court to secure its enforcement. The court is allowed but a limited field for its inquiry. Its duty is simply to find out whether the order has been "regularly made" and "duly served." Having determined those questions in the affirmative, it is subject to the imperative duty of enforcing the order. But two observations should be made in this connection. It may be suggested that the courts might interpret the words "regularly made" as justifying an inquiry at large into the reasonableness of the rates. This, however, is most improbable, as it would surely be doing gross violence to the language. It might also be asked whether this provision would not destroy all power in the courts to consider the amount of the rates. Surely not. For the right to determine whether they are too low to be constitutional exists independent of statutory enactment. The courts always enjoy the right of testing the reasonableness of rates according to the constitutional standard; but this clause of section 16 seems to forbid the employment of any other test.

It is also not without significance that in section 15 the commission is authorized to "establish through routes and joint rates," there being no requirement that the rates be reasonable. This certainly indicates that joint rates are subject only to the constitutional test. But if joint rates, why not other charges as well?

We reach, therefore, the conclusion that when a case has arisen under the act and has been finally decided, the advocates of a broad review-of the remuneration test-will in all probability find themselves defeated, and that the commission will be at liberty to reduce rates as far as the constitution will permit. ${ }^{18}$ That this outcome is heartily to be desired cannot be doubted. Experience has shown that the state commissions have suffered greatly from judicial review, though that review has rested exclusively upon a constitutional

\footnotetext{
18 Whether this will be true so far as sleeping car companies are concerned is an interesting question. The tendency of American courts has been to deny that the sleeplng car business is public in character. If this vlew is taken by the Supreme Court, the dista of Justice Brewer in Cotting v. Kansas City Stock Yards Company, mentloned above, will become important. For if they are adopted by the court, sleeplng car companies will be entltled to rates judged by the test of remuneration.
} 
basis, ${ }^{10}$ and the Interstate Commission will doubtless encounter the same obstacles. The difficulties will be great enough under a "constitutional review." They would be insurmountable under a "remuneration review." The "power" of the commission would be little more than nominal.

5. Provisions to Expedite Judicial Review.-It was generally acknowledged in Congress that, while judicial review is inevitable and in some ways desirable, it nevertheless presents some disadvantageous features. Among these may be mentioned the delays necessitated by carrying a case through the courts. If rates are suspended pending a final judicial judgment upon their reasonableness, their enforcement may be postponed a matter, not of months, but of years. And that this impairs, and in most cases annihilates, their efficacy is evident. But it seemed to Congress that this incident of judicial review might be met, at least in part, by legislation. Accordingly, the task was undertaken of devising methods to avoid the difficulty, or to mitigate its effects.

The only expedient which finally found a place in the act was designed to hasten the judicial proceedings instituted to annul the commission's rates, or to enforce any order of the commission or any provision of the act. For that purpose the provisions of the Expediting Act of 1903 were, with some modification, made applicable to all such suits. It is now the duty of the attorney general, when any such action is begun, to file with the clerk of the court a certificate declaring "that, in his opinion, the case is of general public importance." "Thereupon such cases shall be given precedence over others, and in every way expedited, and be assigned for hearing at the earliest practical day," with the proviso, however, that when the action is to restrain the enforcement of an order of the commission, that body shall have at least five days notice prior to the hearing. An appeal is allowed, even, it seems, from an interlocutory decree, but must be taken within thirty days, and only to the Supreme Court, in which it has priority over all causes, except causes of like character and criminal causes. These provisions will no doubt prove useful, though even with their aid the complete trial of a case will doubtless consume many months.

Two other expedients were proposed, but neither adopted. One contemplated the filing of a bond by the railroad, pending judicial

w polnt elaborated in the author's "Rallroad Rate Control," supra ot. 
review, the purpose of the bond being to assure repayment to each shipper of the overcharge should the rates finally be sustained. The obvious weakness of this plan was that the shipper is not always the party injured by the extortion. The second-a more thoroughgoing plan-proposed that the rates should be made effective pending judicial investigation; that, in other words, the courts should be forbidden to delay their enforcement by the issue of temporary injunctions; that no restraining order should be issued until they should be found to be unreasonable. This proposal seemed eminently reasonable, in view of the accepted canon of statutory construction, that if the constitutionality of a statute is in doubt, the statute must be sustained. Only when its unconstitutionality is proved beyond a reasonable doubt should it be set aside. Now it is recognized by the courts that rates made either by legislatures or commissions are acts of legislation. They should therefore not be annulled until their unconstitutionality is clearly established, which cannot occur until the conclusion of judicial proceedings.

But in spite of all that could be said in its favor, the proposal was vigorously and bitterly opposed. The merits of the question, however, were little considered, for the discussion speedily took the form of a so-called constitutional debate. The right of Congress to limit the judicial power was called in question. It was argued that while Congress could create or abolish the federal courts, other than the Supreme Court, it could not prevent them while existing, from exercising all judicial functions, both legal and equitable, which existed when the constitution was adopted, and which included the power to issue injunctions. On the other hand, it was contended that Congress in creating any particular courts could confer upon them whatever powers it deemed wise. Into the details of these arguments we need not go. The opposition won, and the proposal was defeated. This is very much to be regretted. Few suggestions for rendering more effective the public regulation of rates have been so full of interest as this. While there is serious doubt as to its constitutionality, there can be no doubt that, if held to be valid, it would be of signal service in strengthening public control of rates, and in mitigating some of the serious evil results of judicial review. For this reason the defeat of the plan is deplorable. Had Congress adopted it and embodied it in the act, its constitutionality, which is now in doubt, could have been speedily 
determined. Were the decision to go against it, no harm could be done. The validity of the balance of the act would not be affected. But were the decision to be in its favor, there would result a great gain for the cause of railroad reform.

It may be added that the doubt of its constitutionality is due not so much to the consideration suggested above as to something else. The contention that Congress is without power to limit the authority of the lower federal courts is not generally accepted as sound, and probably would not be upheld by the Supreme Court. But there is another ground on which the railroads could base their claim to the temporary injunction. There is no doubt that they are entitled, under the constitution, to a reasonable income from their business. And there is no doubt that if compelled for a year or so to operate rates too low to yield that income, they would be in a sorry plight. When the courts had determined that the rates were unreasonably low, their only remedy would be to sue each shipper for the difference between the charge paid and the reasonable charge, and this would result in a multitude of trivial and unprofitable suits. All this has been repeatedly recognized by the courts, which declare that a railroad suffers irreparable injury if it must operate unreasonable rates pending judicial review. Therefore the courts have held that in order to protect the company in its constitutional rights, injunctions must be issued at the outset to stay the enforcement of the rates. This right to equitable relief is now firmly established. Thus we find the Supreme Court approving a decree of injunction issued by a circuit court to restrain the enforcement of rates made by a state commission, although the state law declared that the rates should be in force pending judicial review. Indeed, we find the court going even farther. In Chicago, Milwaukee and St. Paul Ry. Co. $v$. Tompkins, ${ }^{20}$ a temporary injunction was issued at the outset, but after a thorough trial the lower court declared the rates to be reasonable and denied a perpetual injunction. Upon appeal, however, the Supreme Court directed that the restraining order be continued pending a final decision of the case. This illustrates how zealous the court is in protecting the constitutional rights of the railroads. In view of the dicta and the practice of the court, it may be asserted with some confidence that a statute denying the temporary injunction in rate cases would be

ॠ176 U. S. 167. 
overthrown by the court on the ground that, in effect, it prevented the courts from protecting the railroads in their constitutional rights. Nevertheless, it is to be regretted that the action, or inaction, of Congress has prevented a definite determination of this very important question.

6. Penalties.-The penal provisions connected with the ratemaking power may be disposed of in a few words. They provide for punishment by fine only. "Any carrier, any officer, representative or agent of a carrier, or any receiver, trustee, lessee, or agent of either of them, who knowingly fails or neglects" to obey the commission's orders establishing rates, "shall forfeit to the United States the sum of five thousand dollars for each offense," and each day of violation is to be regarded as a separate offense.

In concluding this discussion of the amended Interstate Com. merce Act, one question of a general nature must be briefly considered. In so far as the act pertains to the regulation of rates by the commission, how effective will it probably be? How well does it equip the commission with powers necessary for the successful control, in the public interest, of railroad charges? The answer to these queries must be the confession that, while the act will doubtless improve existing transportation conditions, it will in all probability prove but moderately effective. It is not in all respects thoroughly adequate. The review given above discloses several weak points. The commission will doubtless be embarrassed by its lack of authority over transportation exclusively by water, by the requirement of a formal complaint in all cases, by its inability to fix a minimum rate, and by the numerous serious difficulties incident to judicial review. In addition, a further obstacle may be found in the failure of the act to confer any right of control over the classification of freight. Two of these defects are probably inevitable under our constitutional system, but, even aside from them, the act is below the standard which might have been attained. Experience, however, will show better than present analysis the respects in which the act must be altered or strengthened before the commission can reach its maximum efficiency. For the present the reflection is possible that, whatever the achievements of the commission may be, the passage of the act has already been justified, for the large number of reductions in rates which have been voluntarily made by the railroads gives evidence that the enactment of the law has not been in vain. 